\title{
REVIEW \\ Plant Breeding in the Turn of the Millennium
}

\author{
Aluízio Borém* and Sandra Cristina Kothe Milach \\ Ph.D. Professor, Departamento de Fitotecnia da UFV, 36.571-000,Viçosa, MG, Brazil E-mail: \\ borem@mail.ufv.br, Ph.D. Professor, Dept. Plantas de Lavoura-UFRGS, C.P. 776, 90.001-950, Porto Alegre, RS
}

\begin{abstract}
The transition from hunting and gathering to farming happened about 10,000 years ago, independently and diffusely in several places in the world. Plant breeders were responsible for genetic progress in a number of crop species. It included hybrids, the introgression of wild species genes and also the Green Revolution, which started in the 1960's with the cereals. The varieties developed by breeding, along with the use of new crop technology (fertilization, soil tillage, etc.) changed the status of some countries from importers to exporters of food. In the turn of the millennium, plant breeding, faces new challenges in a globalized world, but it has new tools to deal with them. Notwithstanding the present contributions of plant breeding and crop management, its future contributions may be even greater. The partnership being developed between plant breeding and biotechnology will assure a more consistent and predictable genetic progress. Current contributions of biotechnology have arrived for many crops in different places of the world. Varieties developed by transformation are grown in large acreage in some countries. Some concerns have also arisen from the use of GMOs. For example, the introgression of a gene for insect resistance 4 into many different species could result in an undesirable endemic risk, here called interespecific biotechnological vulnerability. Another concern is that biotechnology race may create yield plateaus in programs using genes pyramiding for all new traits made available by biotechnology, resulting in what is called genetic gridlock. Nevertheless, the benefits of using biotechnology will substantially enhance the contributions of plant breeding to human life
\end{abstract}

Key words: Plant breeding, Perspectives, Interespecific biotechnological vulnerability, Genetic gridlock, $21^{\text {st }}$ Century, Partnerships

\section{INTRODUCTION}

Plant breeding has been part of agriculture since its beginning. In fact, it is difficult to say whether agriculture influenced plant breeding or vice-versa. Most probably, both have evolved together towards enhancing the quality and yield of cultivated crops. From the beginning of agriculture until today, plant breeding has undergone many changes but even more changes are likely to occur in the future.

\footnotetext{
* Author for correspondence.
}

Many questions arise as to how and in what direction plant breeding will evolve. The $20^{\text {th }}$ century has certainly witnessed great advances in the practice of plant breeding such as mechanization, specialized harvest machinery, computerized breeding programs and instant data processing and availability. Positive contributions have also been made by numerous disciplines and technologies including genetics, statistics, biochemistry, physiology, quantitative genetics, mutagenesis, cell and tissue culture and, more recently, molecular biology. All these advancements have generated 
a great expectation with respect to what is in store in the next millennium.

Although it is impossible to predict the future, it is advantageous to review various disciplines and technologies and reflect on the future of plant breeding. Thus, the main objective of this paper is to revisit plant breeding history and discuss its partnership with biotechnology.

\section{The Agricultural Revolution}

According to historical and archaeological data, farming has been an essential part of human evolution and activity (Harlan, 1992). It is believed that man has existed for at least 2 million years. While little is known about his food habits it is generally accepted that they were hunters and gathered fruit, roots, nuts and grain as sources of food. Farming to produce food was not practiced until approximately 10,000 years ago.

Plant and animal domestication likely occurred in many places simultaneously, promoting a remarkable change in the way man obtained food, thus food gathering was gradually replaced by agriculture, a transition known as the Agricultural Revolution (FLANNERY, 1973). It is supported that man has domesticated only about 100 to 200 species, of which less than 15 currently provide most of human diet (Conway \& Barbier, 1990). These 15 species may be grouped into the following classes: a) cereals: rice, wheat, corn, sorghum, and rye; b) roots and stems: beet, sugar cane, potato, cassava and yam; c) legumes: beans, soybeans and peanuts; and d) fruits: citrus and bananas.

The Russian Nicolai Ivanovich Vavilov identified the geographic regions based on plant species diversity. $\mathrm{He}$ identified eight geographically isolated regions, which were called centers of origin: 1 . Chinese; 2 . Indian; 2a. Indo-Malaysian; 3. Central Asian; 4. Near Eastern; 5. Mediterranean; 6. Abyssinian; 7. South Mexican and Central American; 8. South American; 8a. Chiloé; and 8b. BrazilianParaguayan (Fig. 1).

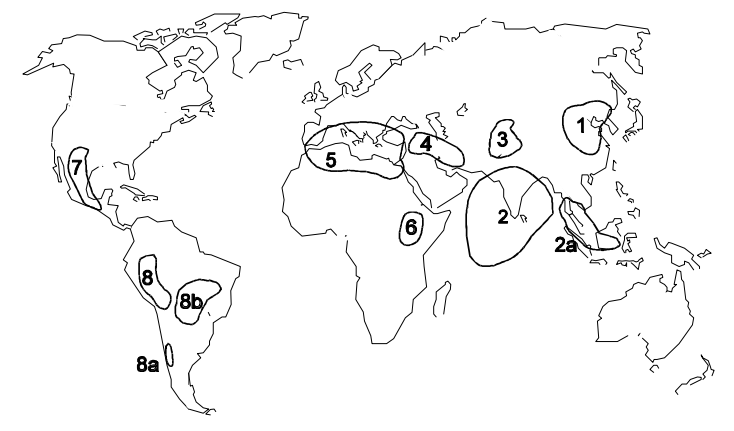

Fig. 1 - Centers of origin of cultivated species, Vavilov (1926).

As suggested earlier, man has evolved from hunter-fisherman-gatherer into an animal raiser and farmer, characterizing the Agricultural Revolution. Agriculture emergence - which underlies all current civilizations - has had several important consequences. First, it resulted in world population growth, probably due to man's ability to obtain a larger and more reliable food supply. Estimates indicate that 250 ha of land would have been necessary to feed one man for a year during Pre-History (Fig. 2) while today 1 ha per person per year is sufficient. Finally, it has increased man's influence over nature, replacing natural ecosystems.

\section{Plant Breeding Enterprise}

The genetic composition of crops today is the result of domestication and breeding during several centuries. But, the question "when was plant breeding started"? remains. Corn and other crop relics show that plant breeding started at the earliest. Plant breeding performed by primitive man may have been the search for adequate species to meet his needs. Maize can serve as an example. It originated in the New World, where it was cultivated by Indians thousands of years ago. It spread over the Americas from Mexico (its probable center of origin), and when Europeans arrived in Mexico, they found hundreds of varieties being used by the various Indian tribes (Galiant, 1992). The germplasm provided by the Indians and other 
ancient people started to undergo a directed breeding process, from the $19^{\text {th }}$ Century onwards. Even though they lacked scientific knowledge, these plant breeders had the ability to select plants for traits important for them. At that time, plant breeding was only an art.

After the rediscovery of Mendel's Laws and with the expansion of other scientific fields, plant breeding began in earnest, developing cultivars in many species. Today, yields of 23.9 t/ha of corn (Witter, 1975) and 7.4 t/ha of soybean (Chou et al., 1977) have been attained. Of course, these yields are possible when superior varieties are combined with environmental improvement i.e., fertilization, irrigation, pest, disease and weed control and other farming management/practices. It's equally true though that these practices alone would not produce high yields without the help of plant breeding

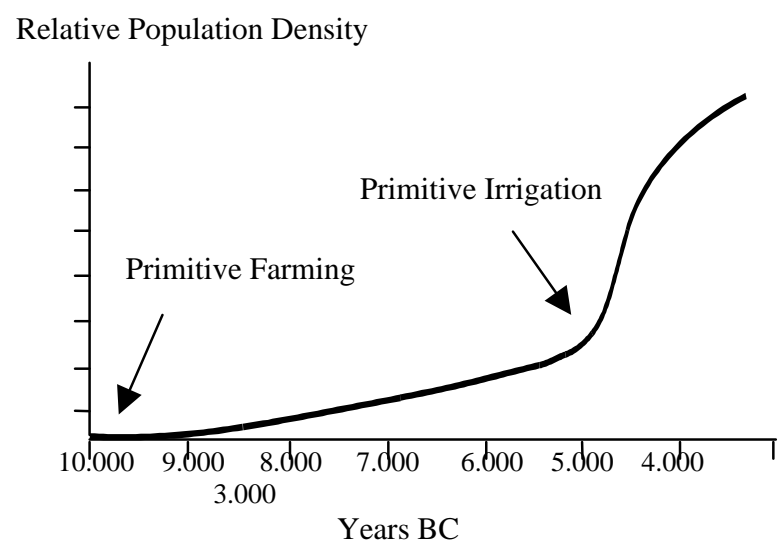

Fig. 2 - Population growth during agricultural transition, Flannery (1973).

In order to reach their objectives, plant breeders have been provided with valuable tools. Hybridization and selection, two main evolution factors, have been intensively applied by plant breeders, cycle after cycle of crossing and selection, resulting in large gains and superior performing varieties in many species.
Mutation, an important factor in evolution, is an additional tool, which has given support to conventional breeding methods, specifically in genetic variability. Male sterility has also been employed since it makes crossing easier and less costly for the development of crosspollinated crops. It also opens new perspectives for the practical use of heterosis, through hybrid varieties of self-pollinated crops (Duvick, 1986).

A new and highly promising tool has emerged more recently - molecular biology. It affords many opportunities including marker- assisted selection and gene transformation.

\section{$20^{\text {th }}$ Century Advancements}

The $20^{\text {th }}$ Century has been characterized by discoveries, which have had a great impact on how plant breeding is conducted. First, the rediscovery of Mendel's laws at the beginning of the century. Around 1910, the concept of heterosis was developed. The 1920's were characterized by the development of classical breeding methods. In the 1930's, there was a great excitement around the discovery of mutagenesis and the use of statistics. In the 1940 's, there were major advancements in quantitative genetics, followed by physiology in the 1950's, biochemistry in the 1960's, tissue culture in the 1970's and molecular biology in the 1980's (Borém, 1998). Duvick (1986), after 45 years of experience in corn breeding, reported witnessing the following major advancements in plant breeding: adopting of new improved machinery and computers; obtaining of two or more generations per year, hence shortening the time for developing new varieties, and the increasing speed in communication among plant breeders worldwide through the use of fax and e-mail.

Scientifically based plant breeding contributions have allowed crops to meet food world demand (Wolf, 1986). The Green Revolution is one of the best examples of plant breeding's social-economic impact on the world. By introducing genes for short-statured 
wheat and later in rice, it has significantly increased their adaptation and grain yield. These new plant types allowed more extensive use of nitrogen fertilizers even in the Third World countries, thus significantly increasing world food production (Borlaug, 1968 and 1969).

Advancements continued with the discovery of the DNA double helix in 1953. Twenty years later, in 1973, the discovery of the restriction enzymes provided further insight into molecular biology. The first transgenic plant, in which a bacterium gene was inserted in a stable way, was produced in 1983. At that time, predictions on biotechnology contributions were made in the media both by laymen and scientists themselves, creating high expectations. The scientific world was dominated by a feeling of euphoria with several large and small enterprises being started, attracted by the prevailing enthusiasm, with most of them soon going bankrupt (Borém, 1998).

While many biotechnology predictions did not come through as expected recent contributions are very impressive. Today, new biotech firms are emerging in a promising market. More realistic expectations and a certain degree of resistance by society against some of the new products obtained through biotechnological processes show that biotechnology is entering a new phase.

The first commercial available transgenic variety was the Flavr-Savr tomato, released in 1996, modified by recombinant DNA techniques by CALGENE Co., to delay post harvest maturation and thus improve flavor. Many other products are now commercially available such as the cotton variety "Ingard", released in October, 1996 in Australia. "Ingard" carries the $\mathrm{Bt}$ gene of the bacteria Bacillus thuringienses that confers resistance to the Lepidoptera insects. About 15 genetically modified products are currently been commercialized in the USA. They included "Roundup Ready" soybean, which is resistant to the herbicide glyphosate, various corn hybrids which possess the Bt gene, some insect and herbicide resistant tomato varieties, virusresistant potato clones and improved canola oil varieties (Kubicek, 1997).

Based on a survey answered by 32 breeders from the public sector and 23 from the private industry in charge of over twenty different crops in several countries, the influence of molecular markers on variety development has been small but promises to be important. The surveyed breeders said they believed that molecular markers would contribute in several ways: marker-assisted single gene introgression, transgene and QTL transference, and parent selection (Lee, 1995). Also according to Lee (1995), the main factors limiting the use of molecular markers to develop cultivars are: technology cost, genotype marker interaction and operational difficulty.

According to Jones \& Cassells (1995), 1990's genetics research at American and European universities has been in some degree oriented towards molecular biology and genetic transformation. Consequently, there is a concern that the number of universities in the First World which offers training in filed plant breeding may decreased in the future.

Cuts in public funding for research and allocation of more resources to biotechnology have resulted in sizeable cuts for conventional plant breeding. This is a virtually insoluble problem but one hopes that research-funding agencies will adopt balanced investment policy that also supports plant breeding now and in the future. During the early years of biotechnology, scientists concluded that biotechnology would not replace conventional breeding. Biotechnologists and breeders have a better understanding of each other, today. Gradually, administrative and legislative organs will have a better insight of the importance of plant breeding and biotechnology.

In regard to the future there are encouraging signs. Several Universities are hiring plant breeders and the importance of a team effort 
involving plant breeder and molecular biologist is routinely accepted by informed scientists and administrators.

\section{Biotechnology's Risks and Benefits}

A new Green Revolution may be needed to increase food production. But will biotechnology lead plant breeding to another revolution? Some evidence already exists which supports this possibility. Almost certainly, transgenic varieties of various species will be grown in the next years. The commercial availability of transgenic varieties on a largescale will generate, similarly to the Green Revolution, new technological packages (such as use of insecticides and other inputs) and will make possible the practice of agriculture on a large-scale. Will such developments bring high risks? In the case of the Green Revolution, there was little risk due to gene escape probably because of its nature, i.e., genes for plant stature. It is certainly different with cotton, maize and soybean varieties, Bt carriers, which confer resistance to Lepidoptera insects (James e Krattiger, 1996). The transformation of different crop species with the same resistance gene, i.e., cloned from the same Bacillus thuringiensis strain may result in an endemic risk, if the insect overcomes the resistance conferred by the Bt gene, a phenomenon we call interspecific biotechnological vulnerability.

Eventually, biotechnology may establish yield level plateaus, based on limits imposed by the pyramiding (Milach \& Cruz, 1997) of genes for the characteristics created via biotechnology or existing in the germplasm, resulting in the so-called genetic gridlock. On the other hand, new perspectives untaught of by the breeder will be created, which may overcome the existing limitations. Transgenic plants will be just a part of the contribution biotechnology promises to deliver to plant breeding. Recently, Tanksley \& Mcoouch (1997) have discussed the importance of the use of genetic resources, from gene banks often also present in wild species. These authors have pointed out that the possibility of accessing the DNA genetic variability by using molecular markers will revolutionize the way this variability will be explored in future plant breeding programs.

\section{CONCLUSION}

Research through the $20^{\text {th }}$ century techniques, complementary to plant breeding, have taught us many lessons. The first lesson was that no technology by itself can substitute for plant breeding. Even so, field evaluation of strains is a fundamental step as long as agricultural is practiced as it has been so far. Another lesson is that any new technology is likely to be adopted for some crops but not all. While induced mutations have a great impact on breeding ornamental crops, they certainly had a less than expected impact on small grains. Likewise, biotechnology might have a big impact on the breeding of some species but it will probably not be important for others. It is believed that the high expectation generated by the use of new techniques and their impulsive, indiscriminate application to any crop species have been the main reasons of disappointment and skepticism. Whether to invest on a new technology, one should first ask how it can help solve the problems faced by breeders and whether it will have a different impact from the classical breeding methodologies. Another question is whether the cost-benefit relation will favor the use of such technology. It is expected that plant breeding in the first decades of the next millennium will continue to evolve but not as drastically. The core germplasm of the cultivated species will remain being the most used gene source. The main methods for the development of new varieties will also be those using hybridization. The costliest stage in variety development will continue being field evaluation for quantitative traits, with the need for interdisciplinary teamwork becoming more evident. Biotechnology will be increasingly incorporated to breeding routine, as a tool in the development of new varieties, conferring more precision to genetic breeding. 
Two of its objectives will be to reduce time for the development of new varieties and to expand the genetic pool available for each breeding program. Which species will be the most affected and how its use will be justified in an everyday breeding situation, will be questions only time will answer.

\section{RESUMO}

A transição da fase de coleta e caça para a agricultura ocorreu há cerca de dez mil anos independentemente e em vários locais no mundo. Naquela época iniciou-se a domesticação da maioria das espécies cultivadas, dando início às atividades agrícolas. Os melhoristas foram responsáveis pelo fenomenal progresso genético de um vasto número de espécies. Incluem-se os híbridos, a introgressão de genes de ancestrais silvestres e a própria Revolução Verde iniciada com os cereais na década de 60. As novas variedades desenvolvidas pelo melhoramento genético, associadas ao uso de tecnologia adequada (fertilizantes, preparo do solo etc.), permitiram que importadores de alimentos se tornassem exportadores. A despeito das contribuições do melhoramento genético e do ambiente, as perspectivas de contribuição no futuro são ainda maiores. Na virada do milênio o melhoramento no mundo globalizado enfrenta novos desafios, tendo a sua disposição novas tecnologias. Acredita-se que ele deva continuar evoluindo em direção a progressos genéticos mais previsíveis de forma gradativa, com o uso da biotecnologia. A parceira estabelecida entre melhoristas e biotecnologistas resultará em benefícios para a sociedade. Atualmente, variedades desenvolvidas via biotecnologia estão sendo cultivadas em grandes áreas em diversos países. Todavia, alguns possíveis impactos negativos da biotecnologia tem sido considerados, a exemplo da vulnerabilidade biotecnológica interespecífica, passível de ocorrer quando, por exemplo, um gene da resistência a uma praga fosse introduzido em várias espécies simultaneamente, resultando na possibilidade de uma suscetibilidade endêmica na eventualidade de quebra desta resistência. A corrida da biotecnologia certamente criará novas perspectivas para o melhorista mas, eventualmente, poderá estabelecer platôs de rendimentos com as restrições impostas pela piramidação de genes para as características criadas via biotecnologia, resultando no que se denomina de arresto gênico.

\section{REFERENCES}

Boehlje, M. \& Scrader, L.F. (1996), Agriculture in the 21st century. J. Prod. Agric, v.9 p.335-341.

Borém, A. (1998), Melhoramento de plantas. $2^{\mathrm{a}}$ edição, Viçosa: Editora UFV, 453 p.

Borlaug, N. E. (1968), Wheat breeding and its impact on world food Supply. Public lecture at the Third International Wheat Genetics Symposium, Australian Academy of Science, p. 5-9.

Borlaug, N. E. (1969), A Green Revolution yields a golden harvest, Columbia J. World Bus. \$:919.

Bouwman, A.J. (1991), Developments in pea breeding and targets for the future. Asp Appl. Biol., v.40, p. 21-228.

Chou, M., Harman Jr., D.P., Kalen, H. and Wittwer, S.H. (1977), World Food Prospects and agricultural potential. New York: Praeger Publishers, , $493 \mathrm{p}$.

Conway, G. \& Barbier, E. (1990), After the Green Revolution. London: Earthscar Press, , 204 p.

Duvick, D.N. (1986), Plant breeding: past achievements and expectations for the future. Econ. Bat., v. 40 p.289-297.

Duvick, D.N. (1996), Plant breeding an evolutionary concept. Crop Sci., Madison, v. 36 , p. $539-548$.

Flannery, K.V. (1973), The origins of agriculture. Ann. Rev. of Anthropic, v. 2, p. 271-310.

Francis, C.A. (1989), Contributions of plant breeding to future cropping systems. In: Plant Breed. Sustain. Agric. Symposium, Las Vegas. Proceedings... Las Vegas: ASA. p. 1-13.

Galiant, W. (1992), Evolution of corn. Adv. in Agron., v. 47, p. 203-229. 
Gotsch, N. and Rieder, P. (1990), Forecasting future developments in crop protection. Crop Prot., v. 9, p. 83-89.

Harlan, J.R. (1992), Crops \& Man, Madison: ASA Press, , $184 \mathrm{p}$.

James, C. \& Krattiger, A. F. (1996), Global review of the field testing and commercialization of transgenic plants, 1986 to 1995: The first decade of crop biotechnology. ISAAA Briefs no. 1. ISAAA: Ithaca, NY, 31p.

Jones, P.W. \& Cassells, A.C. (1995), Criteria for decision making in crop improvement programmes - technical considerations. Euphytica, Wageningen, v. 85 p. 465-476.

Kubicek, Q.B. (1997), Panorama da biotecnologia nos EUA. Biotec. Cien. \& Desenv., Brasília, v. 1, p. 38-41.

Lee, M. (1995), DNA markers and plant breeding programs. Advances in Agronomy, v. 55, p. 265-344.

Milach, S. C. K. \& Cruz, R. P., (1997), Piramidação de genes de resistência às ferrugens em cereais. Ciência Rural, Porto Alegre, v. 27, n.4, p.685-689.
Paterson, A.H; Tanksley, S.D. \& Sorrels, M.E. (1991), DNA markers and plant improvement. Advances in Agronomy, v. 55, p. 265-344.

Reed, J.F. (1982), A changing agriculture and our role in it. Crops and Soils, v. 34 p.5.

Swegle, S. (1991), Globalization of agriculture. Arlington, VA: Winrock, , 189p.

Tanksley,S.D. \& Mccouch, S.R. (1997), Seed banks and molecular maps: unlocking genetic potential from the wild.. Science, 277:53295335.

Vavilov, N.l. (1926), Studies on the origin of cultivated plants. Leningrad: Institute of Applied Botany and Plant Breeding, , $78 \mathrm{p}$.

Witter, S.H. (1975), Food production technology and resources base. Science, v. 188, p. 579-584.

Wolf, E.C. (1986), Beyond the Green Revolution. Worldwatch paper 73. 